\title{
PENGELOLAAN ALOKASI DANA DESA (ADD) UNTUK KEPENTINGAN PEMBANGUNAN DAN PEMBERDAYAAN MASYARAKAT \\ (STUDI KASUS DI DESA PATAS, KECAMATAN GEROKGAK, KABUPATEN BULELENG)
}

\author{
NI KADEK SANCHI KRISNA DEWI, LUH PUTU SURYANTINI, NI KOMANG \\ SUMITARIANI, NI GST AYU PT SURYANI, NI WAYAN SANTI WIDIARI
}

Jurusan Akuntansi, Universitas Pendidikan Ganesha, Singaraja, Bali, Indonesia

\begin{abstract}
Abstrak
Penelitian ini bertujuan untuk mengetahui sistem perencanaan rancangan anggaran biaya alokasi dana desa patas yang disusun oleh pemerintah desa dan oleh para teknisi, bagaimana pelaksanaan penggunaan dana di desa patas, bagaimana penatausahaan alokasi dana desa patas, bagaimana pertanggungjawaban yang dilakukan desa patas setelah dana cair dan setelah digunakan , dan bagaimana pelaporan pertanggungjawaban penggunaan alokasi dana desa patas. Program dana desa yang direncanakan untuk pembangunan masyarakat desa Patas, Kecamatan Gerokgak, Kabupaten Buleleng terdapat pembangunan perbaikan Pura, perbaikan jalan, posyandu, gaji karyawan perangkat Desa, dan pembangunan lainnya. Salah satunya yaitu rabat beton di Desa Patas. Sehingga pembangunan rabat beton tersebut hingga saat ini belum dapat direalisasikan secara maksimal. Selain itu diakibatkan oleh ketidakmampuan para aktor pengelola dana yang melibatkan aparat desa yang faktanya belum memiliki kompetensi yang cukup untuk mengelola dana itu. Kondisi inilah yang menyebabkan banyak program pemberdayaan oleh pemerintah tertunda dan tidak tepat waktu dalam implementasinya.
\end{abstract}

Kata kunci: Pengelolaan, Alokasi Dana Desa, Pembangunan, Pemberdayaan

Abstract

This study aims to find out the planning system of the Patas village budget allocation budget plan prepared by the village government and by the technicians, how to implement the use of funds in Patas village, how to administer the Patas village fund allocation, how the accountability is done by Patas village after the funds are disbursed and after used, and how accountability is reported for using patas village fund allocations. The village fund program that is planned for the development of the Patas village community, Gerokgak Subdistrict, Buleleng Regency has the construction of temple improvements, road repairs, posyandu, Village staff salaries, and other developments. One of them is concrete rebate in Patas Village. So that the construction of concrete rebates has not yet been realized to the fullest. In addition, it is caused by the inability of the fund management actors involving village officials who, in fact, do not yet have sufficient competence to manage the funds. This condition causes many government empowerment programs to be delayed and not timely in their implementation.

Keywords: Management, Village Fund Allocation, Development, Empowerment

\section{Pendahuluan}

Dalam sistem pemerintahan nasional terdapat mata rantai sistem pemerintahan mulai dari pusat, daerah, dan desa, maka desa merupakan mata rantai yang terlemah. Hampir segala aspek menunjukan betapa lemahnya kedudukan dan keberadaan desa dalam konstalasi pemerintahan. Padahal desalah yang menjadi pertautan terakhir dengan masyarakat yang akan membawanya ketujuan akhir yang telah di gariskan sebagai cita-cita bersama. Dengan adanya Program dana desa yang diambil dari hasil pajak daerah dan retribusi daerah kabupaten/kota sebagai alokasi dana desa. 
Desa merupakan ujung tombak pelaksanaan pemerintah paling terdepan dalam sistem penyelenggaraan Pemerintahan Negara Indonesia. Dalam hal ini maka pemerintah menyalurkan dana ke setiap desa melalui APBN kemudian dari APBN di salurkan melalui DAK (dana alokasi khusus) kemudian disalurkan kembali melalui ADD (Alokasi Dana Desa). Berkenaan dengan filosofi Dana Desa adalah meningkatkan kesejahteraan dan pemerataan pembangunan desa melalui peningkatan pelayanan publik desa, memajukan perekonomian desa, mengatasi kesenjangan pembangunan antara desa serta memperkuat masyarakat desa sebagai subjek dari pembangunan. Sesuai dengan Undang-Undang No 6 Tahun 2014 tentang desa maka desa di berikan keleluasaan untuk mengatur kewenangannya, baik kewenangan berdasarkan hak asal usul, maupun kewenangan lain yang di tugaskan Pemerintah sesuai dengan tugasnya.

Lembaga kemasyarakatan di desa tidak hanya di beri pengaturan tentang tugas pokok dan fungsi dan organisasinya tetapi perlu didukung dalam segi dana untuk operasional kegiatan baik itu dari pemerintah desa melalui program Dana Desa. Pembangunan desa bertujuan meningkatkan kesejahteraan masyarakat desa dan kualitas hidup manusia serta meningkatkan daya saing melalui pemahaman kebutuhan dasar, pembangunan sarana dan prasarana desa, pengembangan ekonomi lokal serta pemanfataan sumberdaya alam dan lingkungan secara berkelanjutan dimana pembangunan desa meliputi tahapan perencanaan, pelaksanaan, dan pengawasan.

Pemerintah telah menetapkan Peraturan Pemerintah No.60 Tahun 2014 tentang Dana Desa yang bersumber dari APBN sebagaimana telah dirubah dengan Peraturan Pemerintah No.22 Tahun 2015. Pokok-pokok pengaturan dalam Peraturan Pemerintah tersebut, antara lain, mengenai mekanisme pengalokasian dan penyaluran Dana Desa, penggunaan dan pelaporan Dana Desa, monitoring dan evaluasi Dana Desa serta roadmap Dana Desa.

Ditetapkan peraturan pemerintah Menteri Keuangan Nomor 93/PMK.07/2015 tentang cara pengalokasian, penyuluhan, penggunaan, pemantapan dan evaluasi Dana Desa, yang mengatur secara detail mengenai tata cara pengalokasian Dana Desa untuk setiap Desa. Sehingga pemerintah Kabupaten/kota diharuskan untuk bisa membangun dan mengalokasikan Dana Desa untuk mendukung jalannya pemerintah desa dan program dari pemerintah.

Kabupaten Buleleng dengan wilayah terluas di bali mendapat kucuran dana desa dari pemerintah pusat di tahun 2017, mencapai Rp 105.860.971.000,-. Dari jumlah itu, setengahnya telah dicairkan keseluruh desa. Di Buleleng tercatat ada 129 Desa. Masingmasing desa mendapatkan alokasi dana desa dengan besaran bervariasi mulai dari yang terendah Desa Sulanyah, kecamatan seririt sebesar Rp 764.551.185,-. Dan yang tetinggi desa Patas, kecamatan Gerokgak Rp 948.226.537. pemanfaatan dana desa itu telah ditentukan oleh pusat, dimana penggunaanya diprioritaskan untuk membiayai kegiatan bidang pembangunan dan pemberdayaan masyarakat.

Pembangunan adalah suatu proses perubahan pembangunan daerah ini menyangkut pembangunan masyarakat seutuhnya maka dari program dana desa ini pemerintah berharap masyarakat ikut serta dan saling bersosialisasi satu sama lain bergotong royong menuju perubahan yang lebih baik dari sebelumnya dan masyarakat ikut terlibat langsung dalam pembangunan untuk dapat bersaing.

Program dana desa yang direncanakan untuk pembangunan masyarakat desa Patas, Kecamatan Gerokgak, Kabupaten Buleleng terdapat pembangunan perbaikan Pura, perbaikan jalan, posyandu, gaji karyawan perangkat Desa, dan pembangunan lainnya. Berdasarkan pengalaman penerimaan dana tahun 2017, maka disusunlah rancangan anggaran tahun 2018 salah satunya mengenai pembangunan rabat beton. Ternyata kembali muncul masalah dalam pelaksanaannya. Hal ini disebabkan karena perbedaan persepsi antara pemerintah desa dengan para teknisi dalam penyusunan anggaran rencana rabat beton tersebut. Sehingga pembangunan rabat beton tersebut hingga saat ini belum dapat direalisasikan secara maksimal. Kondisi inilah yang menyebabkan banyak program pemberdayaan oleh pemerintah tertunda dalam implementasinya. Itulah sebabnya penulis tertarik untuk melihat sejauh mana pengelolaan Alokasi Dana Desa (ADD) itu untuk 
kepentingan pembangunan dan pemberdayaan masyarakat melalui penelitian ke Desa Patas, Kecamatan Gerokgak, Kabupaten Buleleng.

Berdasarkan permasalahan diatas, rumusan masalah dalam penelitian ini yaitu Bagaimana sistem perencanaan rancangan anggaran biaya alokasi dana desa patas yang disusun oleh pemerintah desa dan oleh para teknisi, bagaimana pelaksanaan penggunaan dana di desa patas, bagaimana penatausahaan alokasi dana desa patas, bagaimana pertanggungjawaban yang dilakukan desa patas setelah dana cair dan setelah digunakan , dan bagaimana pelaporan pertanggungjawaban penggunaan alokasi dana desa patas.

\section{Hasil dan Pembahasan}

\subsection{Sistem Perencanaan Rancangan Anggaran Biaya Alokasi Dana Desa Patas Yang Disusun Oleh Pemerintah Desa Dan Oleh Para Teknisi.}

Sistem perencanaan rancangan anggaran biaya alokasi dana desa patas yang disusun oleh pemerintah desa dan para teknisi itu berbeda. Dimana rancangan anggaran biaya kegiatan Pembangunan dan Pemeliharaan Jalan dan Jembatan Desa yang disusun oleh aparat kantor desa patas adalah sebagai berikut:

- Rabat beton, 1.2.3, Volume: 118,75 M³ , Jln. Syahridin RT.07, Br Dinas Tegalsari (Rp 125.596.790).

- Rabat beton, Volume: 218,75 $\mathrm{M}^{3}$, Jln. Anggur, RT.03 Br Dinas Mertasari (Rp 278.640.180).

- Rabat beton, 1.2.3, Volume: 153,25 M³ , Jln. Yudistira RT.06-07, Br Dinas Tegal Asri (Rp 196.684.800).

- Perkerasan jalan dan 2 Plat beton, 1.2.3, Volume: 188,52 M³, RT.06, Br Dinas Yehbiyu Kelod (Rp 20.122.950)

- Senderan Jalan, 1.2.3, Volume: 165,5 M³ , Jln. Kendari RT.01, Br Dinas Yehbiyu (Rp 163.328.880).

Namun rancangan tersebut tidak disetujui oleh para teknisi. Hal yang menjadi perbedaan di anggaran yang dirancang oleh pihak desa dengan pihak teknisi adalah pada besaran atau jumlah upah yang diberikan oleh pihak desa kepada pihak teknisi. Dimana para teknisi menetapkan bahwa presentase honor yang mereka peroleh adalah sebesar $30 \%$ dari total anggaran rabat beton. Hal inilah yang menjadi permasalahan didalam pelaksanaan program kerja pembangunan rabat beton di desa patas. Untuk mengatasi permasalahan ini pihak desa dan pihak teknisi sempat mengadakan rapat terkait dengan perbedaan rancangan anggaran biaya yang disusun. Rapat tersebut menghasilkan keputusan yaitu pihak desa harus mengadakan perubahan terhadap rancangan anggaran biaya yang disusun.

Setelah hasil rapat tersebut disepakati maka pihak desa segera melakukan perubahan rancangan anggaran biaya terkait program kerja tersebut. Kemudian pihak-pihak terkait di kantor desa melakukan penyusunan ulang anggaran dengan pertimbanganpertimbangan yang mengacu pada rancangan yang disusun oleh para teknisi. Rancangan anggaran biaya setelah perubahan adalah sebagai berikut:

- Rabat beton, 1.2.3, Volume: 118,75 M³ , Jln. Syahridin RT.07, Br Dinas Tegalsari (Rp 151.809.640).

- Rabat beton, Volume: 218,75 $\mathrm{M}^{3}$, Jln. Anggur, RT.03 Br Dinas Mertasari (Rp 274.836.960).

- Rabat beton, 1.2.3, Volume: 153,25 M³, Jln. Yudistira RT.06-07, Br Dinas Tegal Asri (Rp 194.222.980).

- Perkerasan jalan dan 2 Plat beton, 1.2.3, Volume: 188,52 M³, RT.06, Br Dinas Yehbiyu Kelod (Rp 144.094.116)

- Senderan Jalan, 1.2.3, Volume: 165,5 M³ , Jln. Kendari RT.01, Br Dinas Yehbiyu (Rp 151.295.670).

Setelah rancangan anggaran biaya yang disusun oleh kedua belah pihak telah disepakati maka rancangan anggaran biaya yang disusun oleh pihak desa diproses lebih lanjut agar rancangan tersebut dapat dengan cepat terealisasi. 


\subsection{Pelaksanaan Penggunaan Dana Di Desa Patas}

Setelah kami melakukan observasi di kantor desa patas, kami mengetahui bahwa anggaran pendapatan dan belanja desa di desa patas adalah sebesar Rp 1.116.420.000. Dimana desa patas memperoleh dana terbesar di kabupaten buleleng. Dana ini digunakan untuk menjalankan program kerja yang disusun oleh desa diantaranya yaitu embung desa, pengembangan tenaga kesehatan dan posyandu, pembangunan TK, pembangunan sarana olah raga dan pemeliharaan MCK komunal.

\begin{tabular}{|l|l|l|}
\hline No & Program Kerja & Jumlah \\
\hline 1 & Embung Desa & Rp 26.514.260 \\
\hline 2 & $\begin{array}{l}\text { Pengembangan Tenaga Kesehatan } \\
\text { Dan Posyandu }\end{array}$ & Rp 20.034.100 \\
\hline 3 & Pembangunan TK & Rp 42.571.790 \\
\hline 4 & Pembangunan Sarana Olah Raga & Rp 41.579.040 \\
\hline 5 & Pemeliharaan MCK Komunal. & Rp 98.146.125 \\
\hline
\end{tabular}

\subsection{Penatausahaan Alokasi Dana Desa Patas}

Penatausahaan adalah kegiatan pencatatan yang khususnya dilakukan oleh bendahara desa, bendahara desa wajib melakukan pencatatan terhadap seluruh transaksi yang ada berupa penerimaan dan pengeluaran. Kepala desa ikut serta dalam melaksanakan penatausahaan keuangan desa dengan cara menetapkan bendahara desa. Penetapan bendahara desa harus dilakukan sebelum dimulainya tahun anggaran bersangkutan dan berdasarkan keputusan kepala desa. Bendahara desa melakukan pencatatan secara sistematis dan kronologis atas transaksi-transaksi keuangan desa yang akan terjadi. Penatausahaan keuangan desa yang dilakukan oleh bendahara desa, dilakukan dengan cara sederhana yaitu berupa pembukuan belum menggunakan jurnal akuntansi. Bendahara adalah perangkat desa yang ditunjuk kepala desa untuk menerima, menyimpan, menyetorkan, menatausahakan, membayar dan mempertanggungjawabkan keuangan desa dalam rangka pelaksanaa APBDes, Ardi Hamzah (2015). Bendahara desa wajib mempertanggungjawabkan uang melalui laporan pertanggungjawaban. Laporan pertanggungjawaban disampaikan setiap bulan kepada kepala desa dan paling lambat tanggal 10 bulan berikutnya. Menurut Permendagri No 113 tahun 2014 laporan pertanggungjawaban yang wajib dibuat oleh bendahara desa adalah:

1. Buku Kas Umum, digunakan untuk mencatat berbagai aktivitas yang menyangkut penerimaan dan pengeluaran kas, baik secara tunai maupun kredit, digunakan juga untuk mencatat mutasi perbankan atau kesalahan dalam pembukuan. Buku kas umum dapat dikatakan sebagai sumber dokumen transaksi.

2. Buku Kas Pembantu Pajak, Buku pajak digunakan untuk membantu buku kas umum, dalam rangka penerimaan dan pengeluaran yang berhubungan dengan pajak serta untuk mencatat penerimaan uang yang berasal dari pungutan pajak dan mencatat penjualan berupa penyetoran pajak ke kas negara.

3. Buku Bank, digunakan untuk membantu buku kas umum, dalam rangka penerimaan dan pengeluaran yang berhubungan dengan uang bank.

Berdasarkan hasil observasi yang dilakukan di Kantor Perbekel Desa Patas, penatausahaan keuangan yang dilakukan oleh bendahara desa sudah dilaksanakan sesuai dengan pertanggungjawabannya dalam pengelolaan keuangan di Kantor Perbekel Desa Patas dengan cara melaporkan hasil pencatatan terhadap seluruh transaksi yang terjadi 
berupa penerimaan dan pengeluaran. Pencatatan yang dilakukan terlihat pada pembukuan yang dibuat bendahara desa seperti buku kas umum, buku kas pembantu pajak, dan buku bank (sudah terlampir dalam Lampiran). Terkait dengan permasalahan yang dihadapi desa patas terlihat tidak ada keterkaitan dengan penatausahaan dana desa.

\subsection{Pertanggungjawaban Yang Dilakukan Desa Setelah Dana itu Cair dan Setelah Digunakan Pada Desa Patas}

Laporan pertanggungjawaban adalah laporan realisasi pelaksanaan APBDesa yang disampaikan oleh Kepala Desa kepada Bupati/Walikota setelah tahun anggaran berakhir pada 31 Desember setiap tahunnyaLaporan pertanggungjawan ini harus dilakukan oleh Kepala Desa paling lambat pada akhir bulan Januari tahun berikutnya. Sejalan dengan prinsip transparasi, akuntabel, dan partisipatif yang merupakan cirri dasar tata kelola pemerintah yang baik (Good Governance), maka pertanggungjawaban tidak hanya disampaikan kepada pemerintah yang berwenang, tetapi juga harus disampaikan kepada masyarakat, baik langsung maupun tidak langsung. Secara langsung, pertanggung jawaban kepada masyrakat bisa disampaikan melalui Musyawarah Desa sebagai forum untuk membahas hal-hal strategis, yang dihadiri BPD dan unsur-unsur masyarakat lainnya. Selain itu, laporan pertanggungjawaban juga dapat disebarluaskan melalui berbagai sarana komunikasi dan informasi seperti papan Informasi Desa, website resmi pemerintah kabupaten.

Alokasi Dana Desa adalah dana yang bersumber dari anggaran pendapatan dan belanja daerah (APBD) kabupaten yang dialokasikan dengan tujuan pemerataan kemampuan keuangan antar desa untuk mendanai kebutuhan desa dalam rangka penyelenggaraan pemerintah dan pelaksanaan pembangunan serta pelayanan masyarakat. Desa patas merupakan desa yang mendapat dana desa terbesar diantara desa yang lain di daerah kabupaten buleleng. Maka sebelum dana itu cair mereka melakukan rencana anggaran biaya yang akan diajukan dan di jalankan. Setelah dana itu cair maka dana itu akan terealisasi sesuai dengan rencana sebelumnya yang telah dibuat setelah itu dari seluruh kegiatan yang telah direncanakan di tahun sebelumnya pada RAB Maka terdapat pertanggungjawaban yang tercantum setelah dilakukan kegiatan tersebut. Pertanggungjawaban penggunaan dana desa merupakan bentuk konsekuensi atas penggunaan dana publik yang dipercayakan kepada pemerintah desa. Dilihat dari bentuk pertanggungjawaban, pada desa-desa kabupaten Buleleng cenderung bersifat administratif. Pertanggungjawaban administratif merupakan pertanggungjawaban pemerintah desa atas kegiatan pelaksanaan Alokasi Dana Desa secara administratif berupa Lembar Pertanggung Jawaban(LPJ). LPJ dibuat sesuai dengan bidang masing-masing bidang seperti kegiatan sosial, kesehatan masyarakat, serta pembangunan. Tetapi, hanya pembangunan saja yang belum terjalankan seperti pembangunan rabat beton yang tidak berjalan sesuai dengan rencana karena perbedaan persepsi antara pemerintah desa dengan para teknisi dalam penyusunan anggaran rencana rabat beton tersebut. Sehingga pembangunan rabat beton tersebut hingga saat ini belum dapat direalisasikan secara maksimal karena pencairan dananya tertunda. Jika dana telah cair dan digunakan sebagai pertanggung jawaban setelah dana itu digunakan maka akan langsumg dibuatkan LPJ sesuai dengan pengeluaran. Proses pertanggung jawaban keuangan desa dimulai dengan urutan sebagai berikut :

a. Kepala Desa menyampaikan laporan pertanggungjawaban realisasi pelaksanaa APB Desa kepada Bupati/walikota setiap akhir tahun anggaran. Laporan pertanggungjawaban realisasi pelaksanaan APB Desa, terdiri dari pendapatan, belanja dan pembiayaan. Laporan pertanggungjawaban realisasi pelaksanaan APB Desa ditetapkan dengan Peraturan Desa. Peraturan Desa tentang laporan pertanggungjawaban realisasi pelaksanaan APB Desa dilampiri:

- Format Laporan Pertanggungjawaban Realisasi Pelaksanaan APB Desa Tahun Anggaran Berkenaan

- Format Laporan Kekayaan Milik Desa Per 31 Desember Tahun Anggaran Berkenaan 
- Format Laporan Program Pemerintah dan Pemerintah Daerah yang masuk ke desa

b. Laporan Pertanggungjawaban Realisasi Pelaksanaan APB Desa merupakan bagian tidak terpisahkan dari laporan penyelenggaraan Pemerintahan Desa.

c. Laporan realisasi dan laporan pertanggungjawaban realisasi pelaksanaan APB Desa diinformasikan kepada masyarakat secara tertulis dan dengan media informasi yang mudah diakses oleh masyarakat. Media informasi antara lain papan pengumuman, radio komunitas, dan media informasi lainnya.

d. Laporan realisasi (semester) dan laporan pertanggungjawaban realisasi pelaksanaan APB Desa disampaikan kepada Bupati/Walikota melalui Camat atau sebutan lain. Laporan pertanggungjawaban realisasi pelaksanaan APB Desa disampaikan paling lambat 1 (satu) bulan setelah akhir Tahun Anggaran berkenaan.

e. Format Rancangan Peraturan Desa tentang APB Desa, Buku Pembantu KasKegiatan, Rencana Anggaran Biaya dan Surat Permintaan Pembayaran serta Pernyataan Tanggungjawab Belanja, Laporan Realisasi Pelaksanaan APB Desa pada semester pertama dan semester akhir tahun serta Laporan Pertanggungjawaban Realisasi Pelaksanaan APB Desa sebagaimana dapat dilihatdalam lampiran buku ini.

f. Ketentuan lebih lanjut mengenai Pengelolaan Keuangan Desa diatur dalam Peraturan Bupati/Walikota.

Pertanggung jawaban penggunaan dana desa terkait permasalahan yang ditemukan belum dapat di laporkan karena rencana pembangunan rabat beton belum dapat berjalan. Maka dana-dana yang telah direncanakan diawal digunakan untuk kepentingan lain.

\subsection{Pelaporan Pertanggungjawaban Penggunaan Alokasi Dana Desa Patas} A. Pengertian Pelaporan Pertanggungjawaban Penggunaan Alokasi Dana Desa

Pelaporan dan Pertanggungjawaban adalah tahapan akhir dalam siklus Pengelolaan Keuangan Desa. Hal-hal pokok yang perlu dipahami berkenaan dengan Pelaporan dan Pertanggungjawaban Pengelolaan Keuangan Desa ini mencakup: pengertian dan makna laporan pertanggungjawaban, tahap, prosedur, dan tatacara penyampaian laporan pertanggungjawaban. Selain itu perlu dihayati bahwa pada hakikatnya laporan pertanggungjawaban Pengelolaan Keuangan Desa adalah pemenuhan tanggungjawab kepada masyarakat/rakyat desa atas pengelolaan uang dan kepentingan rakyat oleh Pemerintah Desa.

Pelaporan merupakan salah satu mekanisme untuk mewujudkan dan menjamin akuntabiltas pengelolaan keuangan desa, sebagaimana ditegaskan dalam asas Pengelolaan Keuangan Desa (Asas Akuntabel). Hakikat dari pelaporan ini adalah Pengelolaan Keuangan Desa dapat dipertanggungjawabkan dari berbagai aspek: hukum, administrasi, maupun moral. Dengan demikian, pelaporan pengelolaan keuangan desa menjadi kewajiban Pemerintah Desa sebagai bagian tak terpisahkan dari penyelengaraan pemerintahan desa.

B. Prinsip Pelaporan dan Pertanggungjawaban Pengelolaan Keuangan Desa

Hal-hal penting atau prinsip yang harus diperhatikan dalam melaksanakan pelaporan ini, antara lain:

- Menyajikan informasi data yang valid, akurat dan terkini.

- Sistematis (mengikuti kerangka pikir logis).

- Ringkas dan jelas.

- Tepat waktu sesuai kerangka waktu yang telah ditetapkan dalam Permendagri.

C. Tahap, dan Prosedur Penyampaian Laporan Pertanggungjawaban ADD Desa Patas.

Pelaporan yang dimaksud dalam Pengelolaan Keuangan Desa adalah penyampaian laporan realisasi/pelaksanaan APBD Desa secara tertulis oleh Kepala 
Desa (Pemerintah Desa) kepada Bupati/Walikota sesuai ketentuan yang telah ditetapkan dalam peraturan perundang-undangan.

Laporan Pertanggungjawaban disampaikan oleh Kepala Desa kepada Camat paling lambat pada akhir bulan Juli tahun berjalan, apabila laporan pertanggungjawaban desa tidak disampaikan maka untuk RAB tahun berikutnya tidak bisa diajukan sampai laporan pertanggungjawaban diserahkan oleh Kepala Desa kepada Bupati/Walikota.

\section{Dokumen Pelaporan dan Pertanggungjawaban Pengelolaan Keuangan Desa}

$>$ Dokumen laporan yang disampaikan adalah sbb:

a. Form Laporan Realisasi Pelaksanaan APBDesa

b. Form Realisasi Laporan Akhir, Untuk laporan akhir

\section{Laporan Pertanggungjawaban}

Laporan Pertanggungjawaban ini pada dasarnya adalah laporan realisasi pelaksanaan APBDesa yang disampaikan oleh Kepala Desa kepada Bupati/Walikota setelah tahun anggaran berakhir pada 31 Desember setiap tahun. Laporan pertanggungjawaban ini harus dilakukan oleh Kepala Desa paling lambat pada akhir bulan Januari tahun berikutnya. Laporan Pertanggungjawaban ini ditetapkan dengan Peraturan Desa dengan menyertakan lampiran:

a. Laporan Pertanggungjawaban Realisasi Pelaksanaan APB Desa sesuai Form yang ditetapkan,

b. Laporan Kekayaan Milik Desa, dan

c. Laporan Program Sektoral dan Program Daerah yang masuk ke Desa.

\section{Pertanggungjawaban Kepada Masyarakat}

Sejalan dengan prinsip transparansi, akuntabel, dan partisipatif yang merupakan ciri dasar tata kelola pemerintahan yang baik (Good Governance), maka pertanggungjawaban tidak hanya disampaikan kepada pemerintah yang berwenang, tetapi juga harus disampaikan kepada masyarakat, baik langsung maupun tidak langsung. Secara langsung, pertanggungjawaban kepada masyarakat bisa disampaikan melalui Musyawarah Desa sebagai forum untuk membahas hal-hal strategis, yang dihadiri BPD dan unsur-unsur masyarakat lainnya. Selain itu, laporan pertanggungjawaban juga dapat disebarluaskan melalui berbagai sarana komunikasi dan informasi: papan Informasi Desa, website resmi pemerintah kabupaten atau bahkan desa.

> Penyampaian Informasi Laporan Kepada Masyarakat

Ditegaskan dalam asas pengelolaan keuangan adanya asas partisipatif. Hal itu berarti dalam pengelolaan keuangan desa harus dibuka ruang yang luas bagi peran aktif masyarakat. Sejauh yang ditetapkan dalam Permendagri, Laporan realisasi dan laporan pertanggungjawaban realisasi/pelaksanaan APBDesa wajib diinformasikan secara tertulis kepada masyarakat dengan menggunakan media yang mudah diakses oleh masyarakat. Maksud pokok dari penginformasian itu adalah agar seluas mungkin masyarakat yang mengetahui berbagai hal terkait dengan kebijakan dan realisasi pelaksanaan APBDesa. Dengan demikian, masyarakat dapat memberikan masukan, saran, koreksi terhadap pemerintah desa, baik yang berkenaan dengan APBDesa yang telah maupun yang akan dilaksanakan.

Mewujudkan Asas PKD dalam Kegiatan Pelaporan dan Pertanggungjawaban. Sebagaimana telah dinyatakan di atas bahwa hakikat Pelaporan dan Pertanggungjawaban adalah Pengelolaan Keuangan Desa dapat dipertanggungjawabkan dari berbagai aspek: hukum, administrasi, maupun moral. Hal itu dapat dipenuhi apabila azas-azas Pengelolaan Keuangan Desa diwujudkan secara baik dan benar. 
Pelaporan penggunaan dana desa terkait permasalahan yang ditemukan belum dapat di laporkan karena rencana pembangunan rabat beton belum dapat berjalan. Maka segera diadakan musyawarah untuk menyamakan persepsi antara pemerintah desa dan teknisi dalam hal anggaran. Tercapainya musyawarah mufakat kemudian akan menghasilkan anggaran yang sesuai dan segera diajukan pencairannya untuk melaksanakan program tersebut.

\section{Simpulan dan Saran}

\subsection{Simpulan}

Program dana desa yang direncanakan untuk pembangunan masyarakat desa Patas, Kecamatan Gerokgak, Kabupaten Buleleng terdapat pembangunan perbaikan Pura, perbaikan jalan, posyandu, gaji karyawan perangkat Desa, dan pembangunan lainnya. Ternyata masih belum sepenuhnya berjalan lancar sesuai dengan tujuan yang di harapkan serta belum sepenuhnya terlaksanakan. Salah satunya yaitu rabat beton di Desa Patas. Hal ini disebabkan karena perbedaan persepsi antara pemerintah desa dengan para teknisi dalam penyusunan anggaran rencana rabat beton tersebut. Sehingga pembangunan rabat beton tersebut hingga saat ini belum dapat direalisasikan secara maksimal. Selain itu diakibatkan oleh ketidakmampuan para aktor pengelola dana yang melibatkan aparat desa yang faktanya belum memiliki kompetensi yang cukup untuk mengelola dana itu. Kondisi inilah yang menyebabkan banyak program pemberdayaan oleh pemerintah tertunda dan tidak tepat waktu dalam implementasinya.

Perbedaan yang terjadi pada tahap perencanaan diatasi dengan mengadakan musyawarah dengan pihak yang bekepentingan (teknisi), sehingga menghasilkan keputusan yang dapat diterima oleh kedua belah pihak. Kemudian segera disusun kembali anggaran yang telah disepakati untuk persepatan pencairan dana agar program rabat beton dapat segera terealisasi. Diakhir masa realisasi anggaran (rabat beton telah selesai) maka akan dibuat laporan pertanggungjawaban yang merupakan tahap akhir yaitu pelaporan.

\subsection{Saran}

Saran untuk pemerintah, terus mengadakan pengawasan terhadap Dana Desa agar dana yang dikeluarkan oleh pemerintah digunakan secara efektif dan efisien serta menghindari adanya penyelewengan terhadap Dana Desa tersebut. Selanjutnya untuk masyarakat umum utamanya warga desa agar turut serta melakukan pengawasan terhadap penggunaan Dana Desa, serta jika terdapat penyelewengan turut serta melaporkannya pada pihak yang berwenang sehingga selanjutnya tidak terdapat lagi kesempatan bagi oknumoknum tertentu untuk melakukan penyelewengan.

\section{Daftar Pustaka}

Aristya Prayudi Made, dan Adi Kurniawan Saputra Komang. 2016. Akuntansi Pemerintahan. Singaraja: Istiqlal Publishing Group.

Dokumen Pelaksanaan Anggaran Perubahan Pemerintah Desa Patas, Kecamatan Gerokgak. Tahun Anggaran 2018.

http://www.bppk.kemenkeu.go.id/publikasi/artikel/417-artikel-perimbangan-keuangan/23373perencanaan-dan-penganggaran-keuangan-desa

https://prezi.com/qw2-ybxywjbz/pelaksanaan-alokasi-dana-desa-add-di-desa-patas-

kecamata/ 